\title{
Linguistic Landscape of Religious Signboards in Ado Ekiti, Nigeria: Culture, Identity and Globalisation
}

\author{
Blessing T. Inya \\ Department of English and Literary Studies, Federal University Oye-Ekiti, Ekiti State, Nigeria
}

\begin{abstract}
This paper focuses on the linguistic landscape (LL) of religious signboards in select areas of Ado Ekiti, Nigeria with a view of establishing the relationship between the languages used on these signboards and the implication for identity, globalisation and culture. Fifty-three LL items were photographed for the study. The areas selected were based on activity level and the number of religious signboards they featured. The data were analysed both quantitatively and qualitatively. The findings revealed the dominance and the pervasiveness of the English language over and across the other languages in the public space. The use of Yoruba texts across the items revealed religio-cultural and loyalist reasons while the use of Arabic confirmed the inherent attachment of the language to Islamic religion, and fostered a religion-based collective identity between the sign writer and the sign reader.
\end{abstract}

Index Terms — linguistic landscape, religious signboards, Nigeria, religio-cultural, collective identity

\section{INTRODUCTION}

Linguistic landscape (LL) is concerned with the use of language in public space. This manifests in the form of any sign or announcement placed outside or inside a public institution or a private business in a given geographical location. It is most often emblematic of the region or territory of use, and thus a symbolic construction of the public space (Adetunji, 2013; Backhaus, 2006; Ben-Rafael, Shohamy, \& Trumper-Hecht, 2006; Cenoz \& Gorter, 2006; Huebner, 2006). LL involves the use of signboards, road signs, billboards etc. to inform, advertise, direct, warn, regulate, or announce to the users of the public space. According to Landry and Bourhis (1997), the linguistic landscape of a given territory, region, or urban agglomeration is the representation of language in the public road signs, advertising, billboards, street names, place names, commercial shop signs, and public signs on government building in those places. It reflects the dominant languages in a city or region and points out which language(s) is (becoming) locally relevant (Shohamy, Ben-Rafael and Barni, 2010).The term, 'Linguistic landscape', was first used in sociolinguistics to mean the way the language situation of a given community or a certain country is described and analysed (Gorter, 2006). This is necessitated by the presence and use of several languages in a large geographical location, and can be found in a social context where there is the use of more than one language in speech and writing, a bi/multilingual situation. It can also be in cases where "the history of language and different degrees in the knowledge of language are considered as well as the internal variation in parts of one language with particular relation to its vocabulary etc." (Gorter, 2006, pp.1-2). This orientation took a new shape over two decades ago with the pilot work of Landry and Bourhis (1997).

Various spheres of the society use sign boards, posters, billboards, graffiti etc. to inform the community of their presence, advertise their products, services or events, regulate people's conduct and interaction. These sectors which may be political, economic, social, religious, cultural, education, are controlled by either an individual or an institution or organisation, all operating within their legal limits (Ben-Rafael et al, 2006), and these individuals or organisations are the agents or actors of the sign that are emblematic of the institution they represent. An important sector of the society, which is germane to this study, is religion.

\section{RELIGION IN NIGERIA}

Religion is a much talked about aspect of the society and it usually attracts serious attention. Some pay attention to religion for its benefits while some others do for the controversies it generates. It is very a slippery concept to define as no two authors have the same conception of who God is or how God should be construed. Also, the multiplicity of religion makes it more difficult to pin it down to a single definition. However, there are some common grounds in people's thought about religion and a major one is the belief in a divine being who created the world and controls the activities of human live. This, therefore, informs the definition of religion as "an institutionalised system of symbols, beliefs, values, and practices focused on the relationship between God and (hu)man, and (hu)man living in society" (Metuh, 1992, p.11). It is a ubiquitous reality in human existence and it entails the presence of a supernatural world and a supreme being to whom humans relate; a relationship expressed in "worship, creeds, beliefs, symbols" (Kitause and Achunike, 2013, p.45-46). 
Nigeria is a nation-state characterised by diversity and complexity of language, culture and religion, its traditions and practices. There are three major religious groups in Nigeria, namely Christianity, Islam and African Traditional Religion (ATR). Other ones can be classified under 'others'. Religion is a major sector of the Nigerian society and it plays a major role in the life of the people. It is a means to life for some as the inspirations they get from the scriptures, sermons, books, revelations, prayers, etc. from the religion define the essence of their lives. Before the advent of the foreign religions, the people around the area now called Nigeria had their system of culture, tradition and of course their religion, which was deeply woven into the systems of the society (Kitause and Achunike, 2013, p.46). This makes ATR the first religion in Nigeria. This religion refers to the religious beliefs and practices of the Africans, native to and originated from Africa and primarily practised mostly by Africans (Kitause and Achunike, 2013, p.46), and can best be described as polytheistic as the people in this area had more than one deity whom they worship. Each deity was expected to cater for different aspects of their lives. Islam came into Nigeria in $11^{\text {th }}$ century through Arab traders and jihadist with a monotheistic structure of worship, Allah; while Christianity was introduced in 15th century through the missionary activities and with the focus on a supreme being called God/Jesus (Akindele and Adegbite, 1999; Ayuba, 2012; Kitause and Achunike, 2013; Tamunobelema, 2015).

Religion, as an important sphere of the society, has received a fair share of linguistic attention. Some studies have looked at ideologies and religious identities in linguistic expressions (Kamalu and Tamunobelema 2013); language volatility and variables in religion (Holt 2006); lexico-semantic analysis language of religion and advertising (Robert and Ukpongetuk 2014), Generic Structure Potential and pragmatic acts in contemporary Christian apologetics (Inya, 2012a, b). Not much attention, as far as the researcher awares, has been paid to the use of signs, posters, notices, billboards and banners by the religious actors in Nigeria and particularly in |Ado-Ekitit, Ekiti State. The current study is influenced by the LL items found in this sector of the society: religious signboards, banners and posters, with particular focus on the politics played with language as a defining factor for particular sub-set in this genre of LL. The pertinent questions here are what languages are used/favoured on particular religious signs, and what implication does the choice have for social, cultural and global identities respectively?

\section{LANGuAgeS AND Religious AtTACHMENTS}

Nigeria was a cluster of autonomous and heterogeneous communities until the colonial amalgamation in 1914 by Fredrick Lugard. These communities spoke different languages though some were mutually intelligible. Around the fifteen century, the English language came into Nigeria through the coastal area trade encounter but it was not the first European language to be spoken on the shores of Nigeria. Portuguese holds that status. English was further entrenched through the activities of the missionaries and traders around early sixteenth century (Tamunobelema, 2015). The contact between English and the indigenous languages (some of which are historically and genetically related) resulted into English-based pidgin. This replaced the Portuguese-based pidgin. The English language has since become "an invaluable legacy of the British which has provided Nigerians with yet another means of expressing their culture" (Akindele and Adegbite, 1999, p.58). The introduction of the English language by the Europeans into the Nigerian linguistic scene expanded the multilingual situation of Nigeria since some of the people were already knowledgeable in indigenous languages other than their own. English language got to Nigeria through trade, missionary activities and colonial administration, and has since then been accorded different statuses in the Nigerian sociolinguistic scenery thereby engraving further the multilingual status of her citizens before the advent of the Europeans. It was first the only language of education and administration, and has since enjoyed the sole status of official language and the lingua franca (Akindele and Adegbite, 1999; Tamunobelema, 2015). Beyond these, it has been the one tool of inter-ethnic communication. However, English as the lingua franca does not mean that it is the only foreign language spoken or with official status in Nigeria; the other exoglossic language (a non-indigenous language approved by the government for official purposes) enjoying official status in Nigeria is French (Akindele and Adegbite, 1999).

Interestingly, Arabic language predates the English language in Nigeria and there are claims that it is the first foreign language to be spoken in Nigeria, between the seventh and tenth century AD (Ayuba, 2012). It is the language of religion (language of the Qur'an and inseparably tied to the Islamic religion), social and cultural purposes before any European language was introduced in Nigeria; spoken and understood by millions of people, used in journalism, broadcasting, education, trade and commerce, particularly in northern parts of Nigeria (Ayuba, 2012; Suleiman, 2014).

Historically, Arabic is native to the Arabian peninsula but was taken out of its home into North Africa through conquest and commerce and then to Biladu-Sudan (i.e. West Africa) into regions like Ghana, Gao, Timbuktu, KanemBornu, Kano and Katsina before the amalgamation of the protectorates of the Niger area. The intrinsic link of Arabic to the Islamic religion advanced its goal of education as Islam was propagated through Arabic pedagogy. According to Suleiman (2013, p.96), "Islam gives prime importance to knowledge and it emphasizes the intellectual learning and practices that modulate an individual into a good citizen." Though, the Arabic language was brought into Nigeria through conquest and trade, it was proliferated through religion and its intrinsic attachment to education, evinced by the large number of Arabic/Islamic schools in northern Nigeria (Ayuba, 2012). The close link between the Arabic language and the Islamic religion is also in the fact that every Muslim is expected to say a part of their prayers in Arabic regardless of the indigenous language (Suleiman, 2014). We can, therefore, draw a conclusion that, unlike the English language, which does not have any attachment to any particular religion, apart from being the language through which 
Christianity was introduced into the already multilingual Nigerian society, Arabic cannot be divorced from Islam, a medium of its proliferation.

The Yoruba language is a Volta-Congo variety of the Niger-Congo languages spoken in some other parts of the world other than Nigeria: Togo, Benin, UK, Brazil USA etc. In Nigeria, the language has a large concentration of speakers in the south-western part, namely Ondo, Ogun, Oyo, Osun, Lagos, Ekiti, and some parts of Kwara. Until the $20^{\text {th }}$ century, Yoruba was the name of a particular group of people believed to have migrated from Arabia through Egypt to West Africa around $7^{\text {th }}$ century. Now, it is used to refer to both the language and tribe that speaks it. The Yoruba were polytheistic. They believed in several gods who were mediums to a supreme deity and this informed their religious affiliations. Even in present times, the Yoruba people still worship these gods, which has been classified as African Traditional Religion (ATR). The language of worship is the indigenous languages of the areas where these worships are conducted.

\section{LITERATURE REVIEW}

The application of linguistic landscape to other forms of study is relatively new and several scholars have applied this to the study of signs in their countries, and even continents. There are studies that focus on cities (Ben-Rafael et al, 2006), countries (Lock, 2003 ), regions (Huebner, 2006), a state in a country (Adetunji, 2013), but only one of these has focused on signage in Nigeria, specifically Ibadan, the capital city of Oyo State and one of the largest cities in Africa (Adetunji, 2013). The study describes the linguistic situation of Ibadan through its LL as representative of Nigerian English. This claim is problematic on the premise that it seems impossible to describe Nigerian English with a study undertaken in only one of the thirty-six states in Nigeria where diversity and complexity are constant referents to the language and culture of the people.

This present study will add to the existing body of knowledge on LL, though best described as a cityscape (Gorter 2006), because of its focus on a particular type of advertising and signage in a city. The relationship between the language(s) found in public space, particularly in religious signage in Ekiti State and their implication for globalisation, social and cultural identity, etc., form the focus of the study. The following assumptions are raised in the study:

1. That the languages used in the signage of the major religions in Nigeria are attached to the missionaries and exponents of such religions. This implies that the attachment of some languages to particular religious signs is generic.

2. That some signs are bi/multilingual due to civilisation/globalisation (to reach wider population), social identity (to boost public image and social acceptance) and cultural identity (mixed or loyalist).

There are three major religions in Nigeria: Christianity, Islam, and the Traditional religion. These religions are seemingly selective of the language used for their signage: stationary and mobile. This study therefore expects to answer the following questions:

1. What language(s) are used in the signage of these religious signboards: advertisements and announcement?

2. What are the generic patterns and the frequency that can be established from the signboards?

3. What are the implications of the identified language use for social, cultural and global identities of the sign producer?

\section{THEORETICAL FOUNDATION}

\section{The Concept of Linguistic Landscape}

Linguistic landscape (LL) is generally described as the use of language in public spaces or a setting or environment of language use in a particular region. It can be described as the scenery of texts found on signs and boards created by private individuals or public (government) in a given environment (Gorter, 2006). It can also be defined as the literal use or representation of language(s) in signs with the importance that relates to identity and cultural globalisation and to the growing presence of the English language in a particular region or territory, especially urban. Therefore, the LL of an urban environment is a mass of written messages and images on public display, contained in a variety of language and scripts, and presented as sign boards, shop signs, advertisements, billboards, traffic signs, topographic information and area maps, political posters, campaigns etc. (Backhaus, 2007, p.1).

Other definitions of LL abound; each definition is unique yet quite similar. Landry and Bourhis (1997, p.25) opines that LL is "the visibility and salience of languages on public and commercial signs in a given territory or region", while Gorter (2006) claims that it is the use of language in its written form in the public sphere, as well as the linguistic object that marks the public space. Landry and Bourhis (1997) thus define LL as "the language of public road signs, advertising billboards, street names, place names, commercial shop signs, and public signs on government buildings... [which combine] "to form the linguistic landscape of a given territory, region or urban agglomeration." (p. 25).

LL may be natural or constructed, static or altered; a physical environment, a context for human action and sociopolitical activity; or a symbolic system of signifier with wide-ranging affordances activated by social action to position themselves and others in that context. Signs in the public spaces do not usually contain only written texts, visuals are sometimes added to the texts to aid the purpose of the signs. These images and texts are always processed together as one unit by the audience and not as separate resources. Adetunji (2013, p. 1) argues that in LL situation, words and 
images are focused on marking the public space. He also points out that the signs and images on these signs are meaning making resources that are processed both physically and cognitively. According to Adetunji (2013, p.2), one of the advantages of the LL is how it "helps us understand the rapidly changing urban landscapes and the increasingly multilingual world in which we live or experience through travel” (Robertson 1995, p.32). There have been linguistic landscape studies on particular regions: Tokyo (Backhaus 2006, 2007); Israeli (Ben Rafael et al, 2006); Ibadan (Adetunji, 2013); Hong Kong (Lock, 2003) etc.; on readers' meaning in interpreting linguistic landscape (Adetunji, 2015), methodological issues (Gorter, 2006; Huebner, 2009) etc. In sum, LL is the use of language, literal or specialised, natural or constructed, etc. in public spaces, and this marks the interface of language and the environment around us. This takes LL outside the strict boundaries of sociolinguistics into an eclectic mix of applied linguistics and other fields of linguistics such as anthropology, media studies etc.

Signs are often conceived as symbols that point to something or represent something else. A sign can take a physical form such as sounds, images, acts etc., and it may stand for something other than itself. The world we live in is as well a world of signs, where our construction and understanding of ourselves, and our environment is that of producing and interpreting signs (Backhaus, 2007, p. 5). These signs are semiotic. These definitions are relevant to this current study: signs are produced for public display and consumption. They are used in order to disseminate messages that are of public/general interest. Public signs are a particular type of semiotic signs because they point to some other thing other than themselves. Some signs are placed directly on the business or company building/premises while some point the direction to the site of the business. Using the triadic terms of semiotic conception of signs, Backhaus (2007) describes the make-up of a sign with index, icon and symbol. Public signs can be categorised into two types, namely top-down or bottom-up signs.

Top-down signs are presented and used by 'institutional agencies which in one way or another act under the control of local or central policies' (Ben-Rafael et al, 2006, p. 14). The LL items in this category include those issued by public institutions, signs on public sites, public announcements and street names. Contained in the LL items issued by public institution are religious LL items. Bottom-up signs are 'utilised by individual, associative and corporative actors who enjoy autonomy of action within the legal units' (Ben-Rafael et al, 2006, p. 14). The LL items here are those issued by individual social actors, e.g. names of shops/business, signs on business and personal announcements, advertisement of products and services (Ben Rafael et al, 2006, p. 14). The signs are produced for and perceived by the public who make meaning of them according to their interpretation of the items. The main difference between these items is that while one reflects a dominant culture and the general commitment to it, the other is more freely expressed to reflect the individual strategy of the social actor.

\section{METHODOLOGY}

Data for this study were collected around three neighbourhoods in Ado Ekiti between July and August 2016. These were selected based on the number of religious signs they feature. Signboards announcing the presence of a religion or advertising religious programmes were photographed, sorted and collated, first according to religion and then according to type of sign: top-down, bottom-up and 'quasi top-down'. From existing literature, the only LL study carried out in Nigeria used Ibadan, the state capital of Oyo, and a city more developed and populated than Ekiti. The study concludes that the LL of Ibadan does not reflect her linguistic situation/representation (Adetunji, 2013). While the previous study looks at reader meaning of place names, and other sociolinguistic features, the present study focuses on the specific language(s) used in producing religious signboards and the implication of their use.

This study combines both quantitative and qualitative methods of analysis. The language use of each group is identified and analysed by considering the language used, dominant languages (in particular signs or group of signs); number of languages, relative font size of different languages, order of appearance, all in relation to the languages identified. These features are subjected to quantitative analysis, and presented in simple percentage. The quantitative and qualitative analyses are used in making informed statement about the language situation of a particular domain of LL in Ado Ekiti. It must be clarified that the categorisation of sign as top-down or bottom-up is based on the leadership and ownership of the religious sign under consideration. A body of religion with regulatory authority is classified as top-down. The church has a head or leader and branches around the country where these branches were created on the directive of the sole leader or board of leaders. These branches are not owned by the local leader and the activities of the local branch are regulated by the general leader. A bottom-up sign refers to signs produced by a body of religious group owned and led by an individual with only one local branch or a couple of local branches while a quasi top-down sign is produced by associative religious group with a regulatory body but each branch is autonomous, and owned by individual spiritual leader. Examples of such religious groups in Nigeria are Celestial Church of Christ and Christ Apostolic Church (Pic. 4.4.1 and Pic. 4.4.2).

\section{DATA ANALYSIS AND DiSCUSSION OF FINDINGS}

\section{A. Christianity-related Public Signs}


TABLE 1.0

SHOWING CHRISTIANITY-RELATED PUBLIC SIGNS

\begin{tabular}{|c|c|c|c|c|c|c|c|c|c|c|c|c|c|}
\hline \multirow[t]{2}{*}{$\mathrm{N}$} & \multirow[t]{2}{*}{ Category } & \multirow{2}{*}{\multicolumn{2}{|c|}{ Type of sign }} & \multirow{2}{*}{$\begin{array}{l}\text { No } \\
\text { of } \\
\text { LL }\end{array}$} & \multicolumn{2}{|c|}{ MnL. no \&\% } & \multirow{2}{*}{$\begin{array}{l}\text { B/ML } \\
\text { no } \\
\& \%\end{array}$} & \multicolumn{2}{|c|}{ Appellation } & \multicolumn{2}{|c|}{ Slogan or motto } & \multicolumn{2}{|c|}{ Theme } \\
\hline & & & & & $\begin{array}{l}\text { Eng } \\
\%\end{array}$ & $\begin{array}{l}\text { Yor } \\
\%\end{array}$ & & $\mathrm{MnL}$ & B/ML & $\mathrm{MnL}$ & $\mathrm{B} / \mathrm{ML}$ & $\mathrm{MnL}$ & $\mathrm{B} / \mathrm{ML}$ \\
\hline \multirow[t]{5}{*}{1} & \multirow[t]{5}{*}{ Top-down } & \multirow{2}{*}{\multicolumn{2}{|c|}{ Signboards }} & & $18=$ & & & & & & & & \\
\hline & & & & 18 & 33.96 & 0 & 0 & 9 & - & 6 & 0 & - & - \\
\hline & & \multirow[t]{2}{*}{ Banner } & Church & 1 & $\begin{array}{l}1= \\
1.89\end{array}$ & 0 & 0 & 1 & - & 1 & 0 & 0 & 0 \\
\hline & & & Programme & 1 & $\begin{array}{l}1= \\
1.89\end{array}$ & 0 & 0 & 1 & - & 1 & 0 & 1 & 0 \\
\hline & & \multicolumn{2}{|c|}{ Posters/others } & 1 & $\begin{array}{l}1= \\
1.89\end{array}$ & 0 & 0 & 0 & - & 1 & 0 & 0 & 0 \\
\hline \multirow[t]{5}{*}{2} & \multirow[t]{5}{*}{ Bottom-up } & \multicolumn{2}{|c|}{ Signboard } & 11 & $\begin{array}{l}10= \\
18.87\end{array}$ & 0 & $\begin{array}{l}1= \\
1.89\end{array}$ & 6 & - & 8 & 0 & - & - \\
\hline & & \multirow[t]{3}{*}{ Banner } & Church & & & & & & & & & & \\
\hline & & & & 3 & $2=3.77$ & $\begin{array}{l}1=1.8 \\
9\end{array}$ & 0 & 0 & - & 0 & 0 & - & - \\
\hline & & & Programme & 9 & $\begin{array}{l}8= \\
15.09\end{array}$ & 0 & $\begin{array}{l}1= \\
1.89\end{array}$ & 1 & 1 & 2 & 0 & 8 & 1 \\
\hline & & \multicolumn{2}{|c|}{ Poster/others } & 0 & 0 & 0 & 0 & 0 & - & 0 & 0 & 0 & 0 \\
\hline \multirow[t]{5}{*}{3} & \multirow[t]{4}{*}{$\begin{array}{l}\text { Quasi Top- } \\
\text { down }\end{array}$} & \multicolumn{2}{|c|}{ Signboards } & 8 & $\begin{array}{l}6= \\
11.32\end{array}$ & 0 & $\begin{array}{l}2= \\
3.77\end{array}$ & 6 & 1 & 4 & 0 & - & - \\
\hline & & \multirow[t]{2}{*}{ Banner } & Church & 1 & 0 & 0 & $\begin{array}{l}1= \\
1.89\end{array}$ & 0 & 0 & 0 & 0 & 0 & 0 \\
\hline & & & Programme & 0 & 0 & 0 & 0 & 0 & 0 & 0 & 0 & 0 & 0 \\
\hline & & \multicolumn{2}{|c|}{ Posters/others } & 0 & 0 & 0 & 0 & 0 & 0 & 0 & 0 & 0 & 0 \\
\hline & & \multicolumn{2}{|c|}{ TOTAL \& \% } & 53 & $\begin{array}{l}47= \\
88.68\end{array}$ & $\begin{array}{l}1= \\
1.89\end{array}$ & $\begin{array}{l}5= \\
9.44\end{array}$ & $\begin{array}{l}24= \\
45.28\end{array}$ & $\begin{array}{l}2= \\
3.77\end{array}$ & $\begin{array}{l}23= \\
43.40\end{array}$ & 0 & $\begin{array}{l}9= \\
16.98\end{array}$ & $\begin{array}{l}1= \\
1.89\end{array}$ \\
\hline
\end{tabular}

(Decimals are approximated to two decimal places, \pm .02 ) KEY TO TABLES ${ }^{1}$

\section{B. Discussion}

Table 1.0 shows 53 LL items grouped under Christian-related public signs with percentage total at $100.02( \pm .02)$. There are 21 top-down Christian related items, 18 are signboards, one concrete sign, one church banner, and one programme banner. All these signs are monolingual, written in English language. The bottom-up items have 11 signboards, three church banners, mostly monolingual though two out of these three are written all in English and one is all in Yoruba. There are nine programme banners; eight out of these items are monolingual (English) while one is bilingual. The quasi top-down items have eight signboards out of which two (4.26\%) are multilingual. Thus, out of the 53 LL items, $48(90.57 \%)$ are monolingual, 47 (88.68\%) are exclusively in English, one (1.89\%) exclusively in Yoruba while five $(9.44 \%)$ are bi/multilingual.

\section{Monolingual LL Items}

A large percentage of the LL items considered are monolingual: out of 53 items, 48 are monolingual, 47 in English and 1 in Yoruba (See Table 1.0). Some of these items represent different branches of the same church. Each of these signs is representative of their other branches, i.e. all The Redeemed Christian Church of God signboards are the same except the parish/province name. The same is the case with Deeper Life Bible Church signboards, Anglican Church, Nigeria; Methodist Church Nigeria, etc. All the signs, whether top-down, bottom-up and quasi top-down, give salience to the English language. There are 21 top-down signs and all are exclusively written in English, 20 out of 21 bottom-up signs and 6 out of 9 quasi top-down signs are in English (Table 1.0).

English Monolingual top-down Christian-related signboards are presented below:

Top-Down LL Items

\footnotetext{
${ }^{1}$ MnL: monolingual

B/ML: bi/multilingual

Alias: alternative appellation or specific tag of identification of the subset of a religious group

Slogan: mission or vision statement, guiding philosophy, etc

Theme: mostly used in events and programmes

Others: LL items on platforms other than the dominant ones used in the study
} 


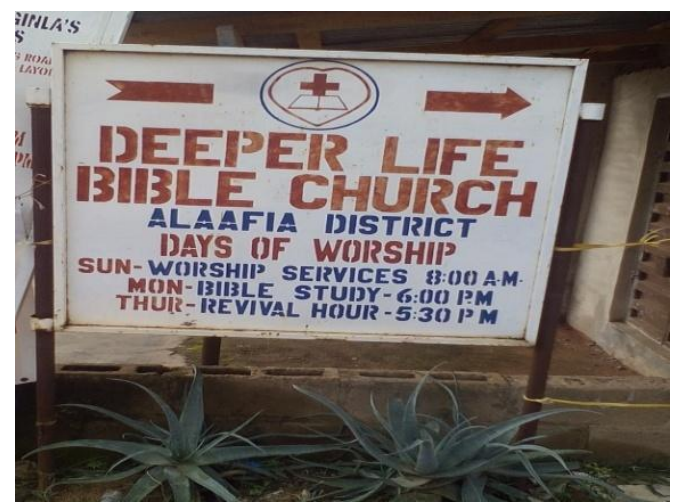

Pic 4.3.1

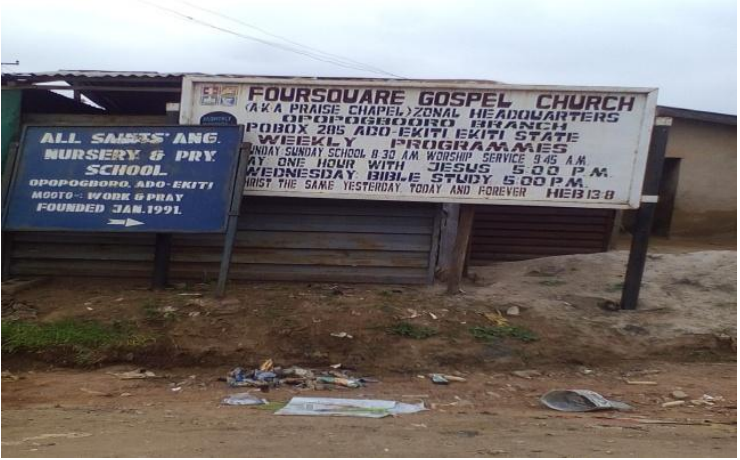

Pic 4.3 .3

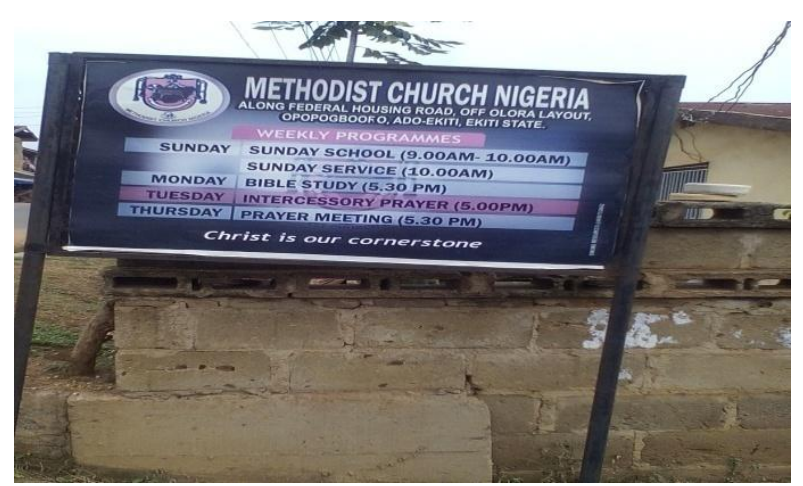

Pic 4.3.5

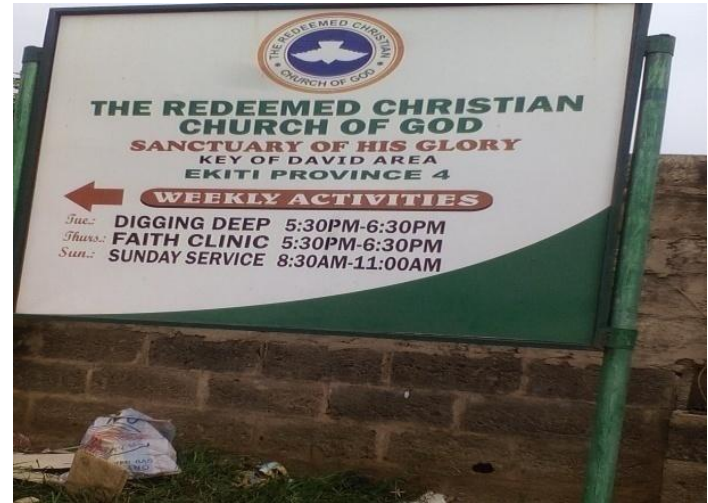

Pic 4.3.2

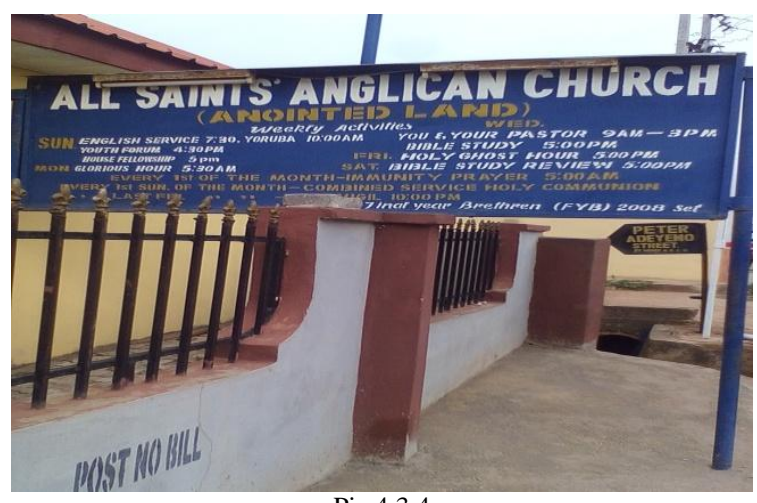

Pic 4.3.4

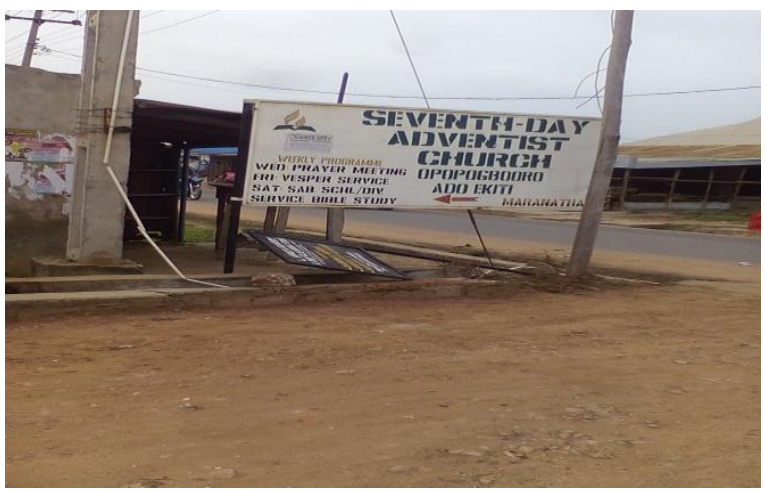

Pic 4.3.6

Some indigenous items found on the signs above are Alaafia, Ekiti, Opopogboro, Adebayo.

Bottom-Up LL Items

Bottom-up signboards are exemplified below:

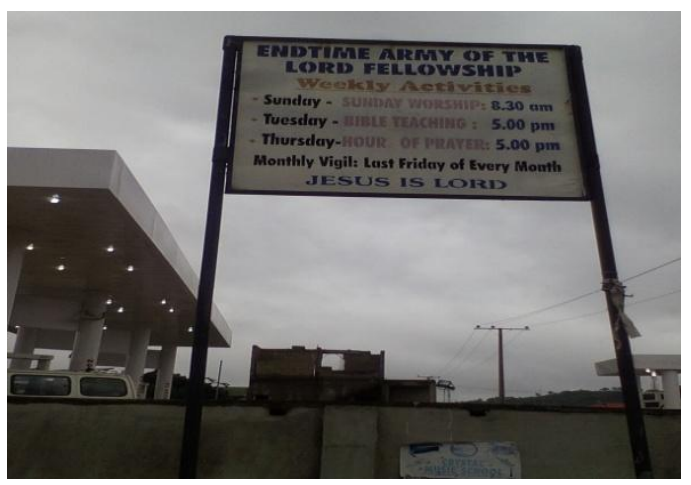

Pic 4.3.7

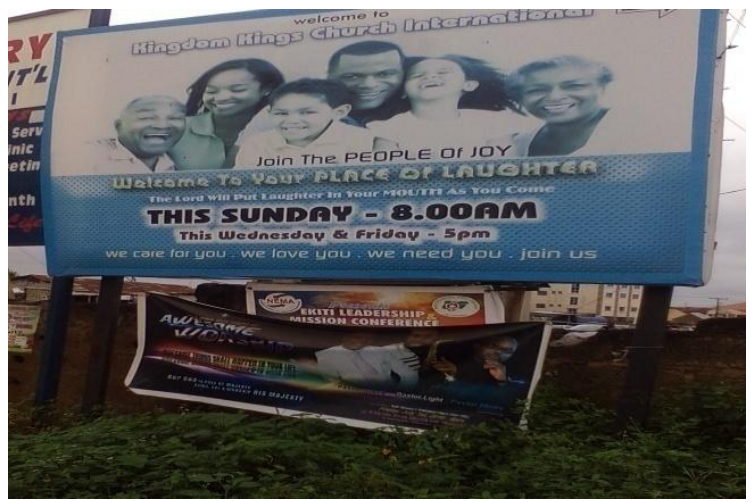

Pic 4.3.8 


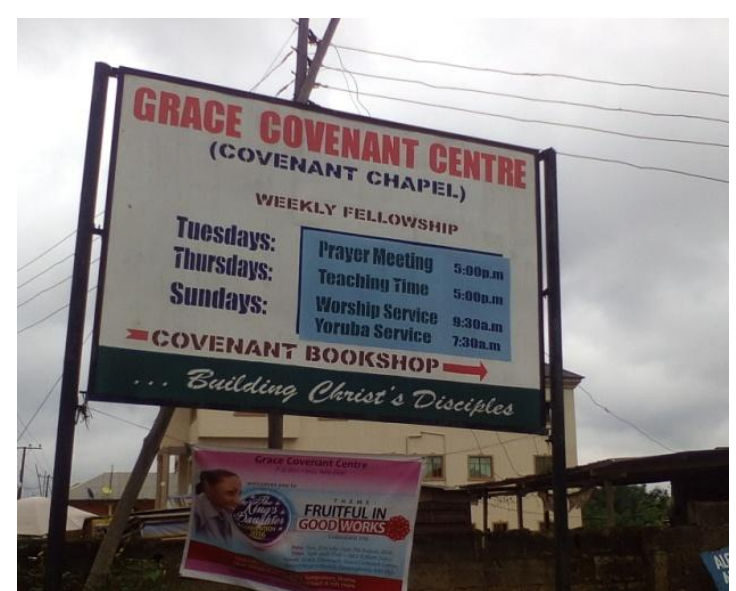

Pic 4.3.9

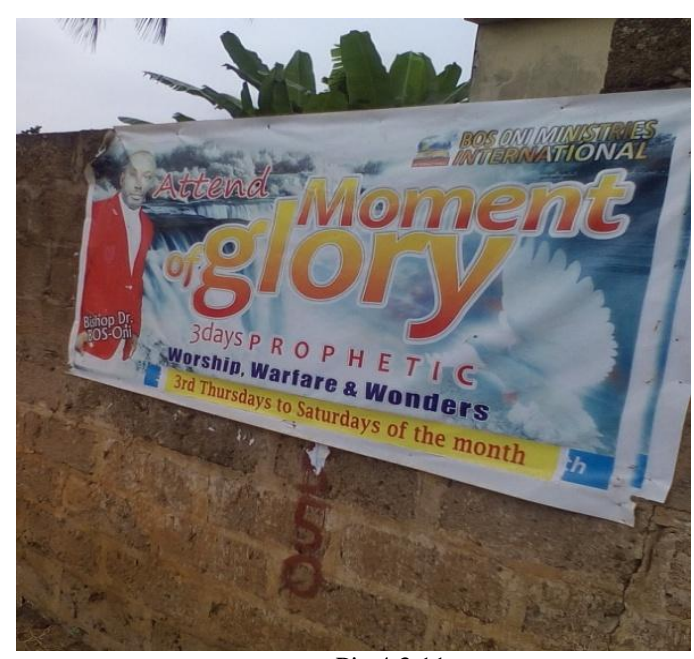

Pic 4.3.11

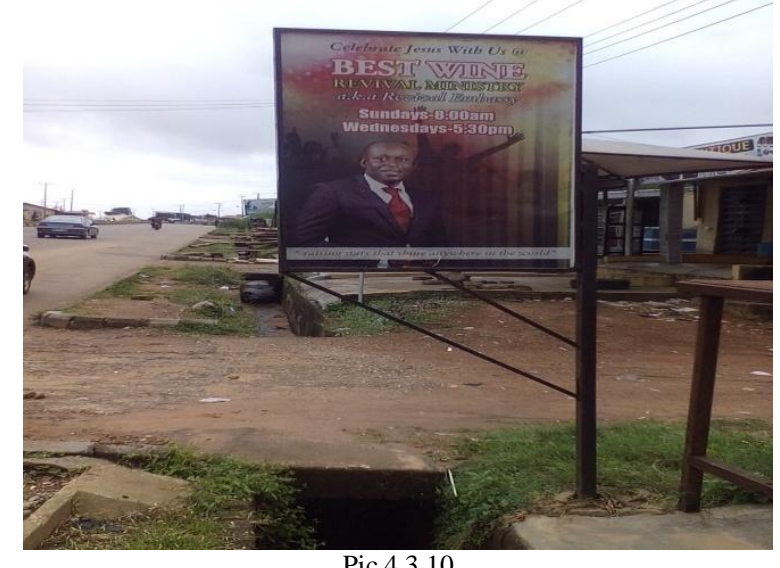

Pic 4.3.10

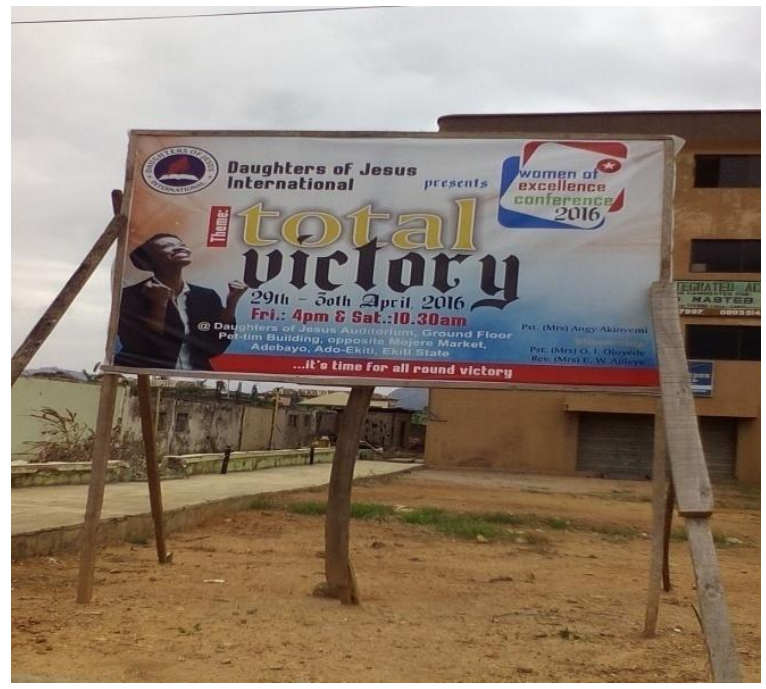

Pic 4.3.12

The bottom-up signs show a predominant use of the English language and no indigenous language. This is engendered by the exclusion of address from the signboards and banners. This can be attributed to the following:

i. The assumption that the readers are familiar with the church or the programme;

ii. The location of the signs: they either are placed on the premises of the church (Pic. 4.3.10-4.3.12) or at a junction very close to the church (Pic. 4.3.7-4.3.9).

Quasi Top-Down LL Items

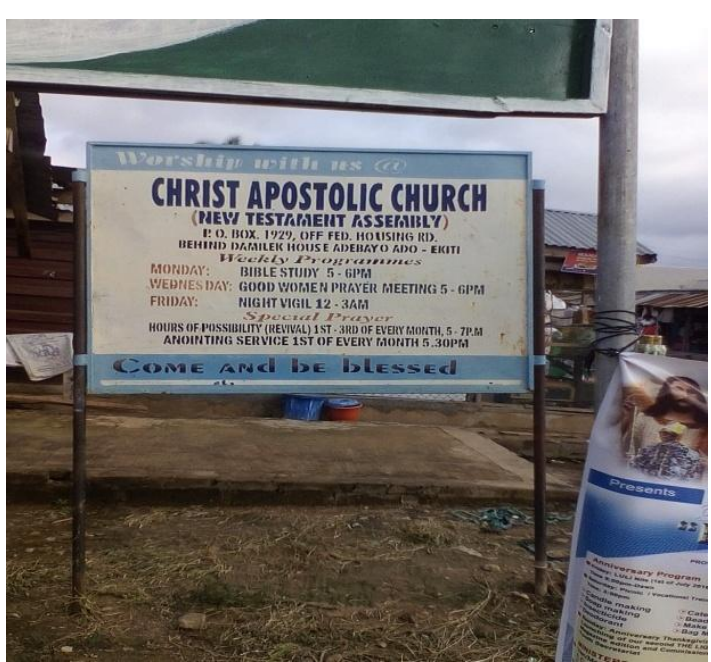

Pic 4.3.13

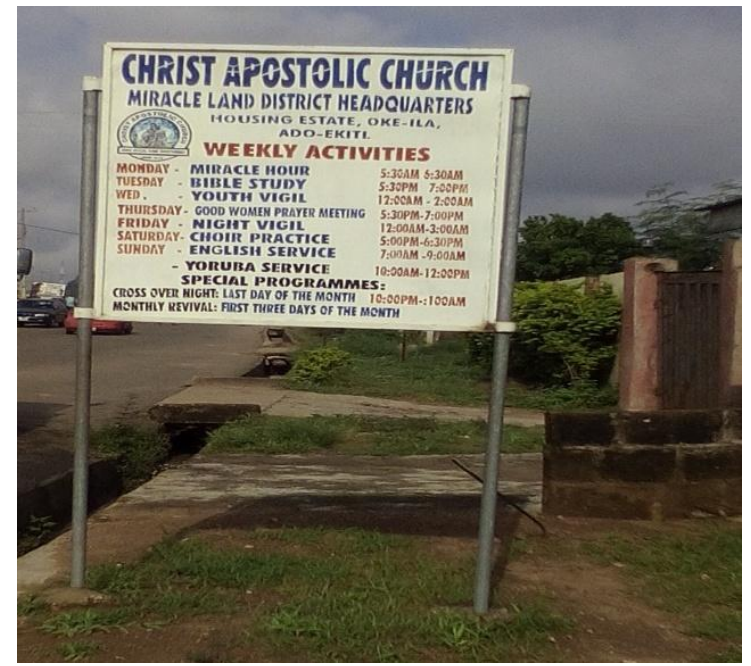

Pic 4.3.14 


\section{Bi/multilingual LL Items}

There are very few cases of bilingual presentation of information in the signs. In Table 1.0, there are $5(9.44 \%)$ bilingual LL items out of the total Christian-related signs. We have the following instances:

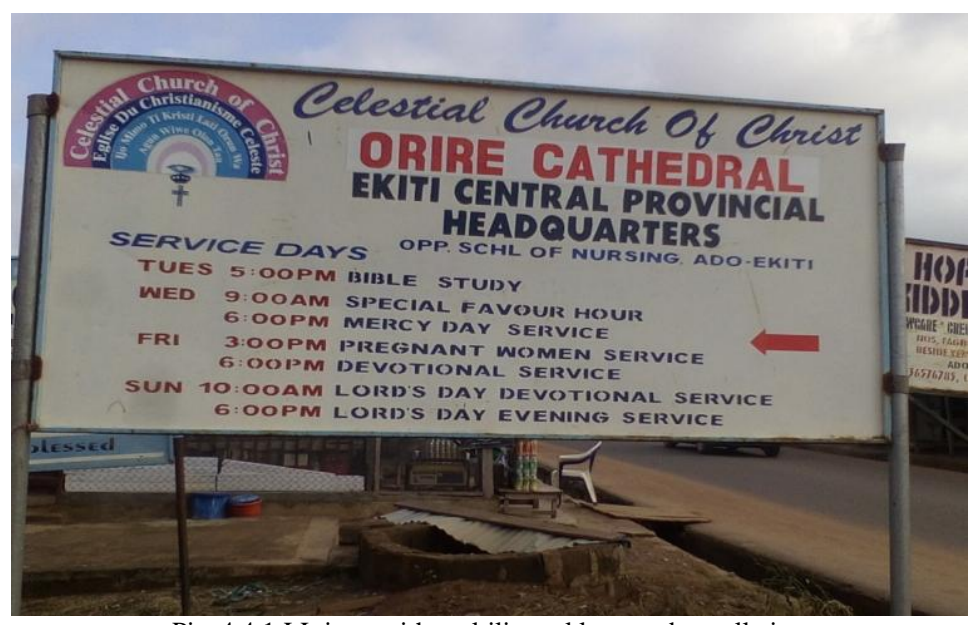

Pic. 4.4.1 LL item with multilingual logo and appellation

Picture 4.4.1 is generically multilingual in that the church name is always written in four languages and the appellation is usually bilingual in Yoruba and English. Each language represents the previous countries of residence of the founder of the church before migrating to Nigeria while the bilingual appellation implies loyalty to the background of the church founder, a Yoruba man, and the nature of worship: a mixture of the religious and cultural beliefs of the Yoruba people (Adogame 1998). English is used as a global language. We have the following languages:

1. English: Celestial Church of Christ

2. French: Eglise Du Christianisme Celeste (original name)

3. Yoruba: Ijo Mimo ti KristilatiOrunwa

4. Egun/Gun: A gun wiweolon ton (Gun/Egun is a language spoken in Benin, and in Badagry, a border town between Nigeria and Republic of Benin).

APPELLATION: ORIRE CATHEDRAL (Orire is a Yoruba word for good luck or fortune).

Orire means good luck, thus, the cathedral promises good luck to those who worship in it.

Another instance of bilingual expression is its use to highlight and consequently draw attention to important information on a sign, with aliases/appellations and brand names to distinguish the branch of a religious sect.

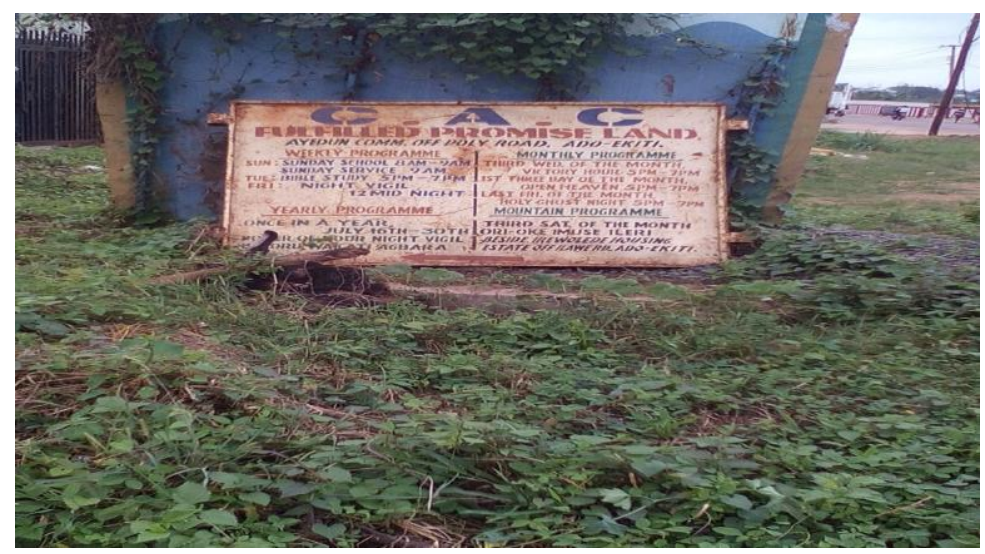

Pic 4.4.2 Item showing highlighted use of English and Yoruba languages

Picture 4.4.2 has YEARLY PROGRAMME written first in red colour, and in English to get the audience attention. Then, the only activity being announced is written in two languages, English and Yoruba.

\section{POWER OF HOUR NIGHT VIGIL \\ ISO ORU WAKATI AGBARA}

Another feature of this sign is the use of Yoruba language to write some parts of the sign without any attempt to translate while the only established connection between the language and the message is the alias of the church:

\section{Ori Oke Imuse Ileri}

\section{Alias: FULFILLED PROMISE LAND}

This can be explained as the idiosyncratic claim of some language/religious loyalists that some important information are best expressed in the indigenous language to capture the weight and magnitude of what is said. It is also to resolve 
any confusion from misunderstanding the name and the programme announced on the signboard. This is using language to specify and differentiate.

For church banners, there is only one instance of bilingual expression found in an aspect of the LL item.

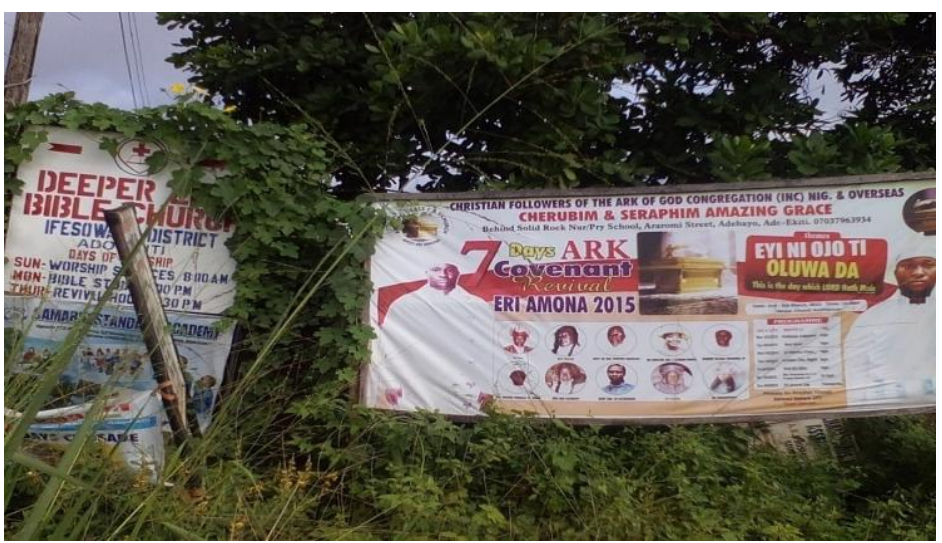

Pic. 4.4.3 LL item with varying degrees of bilingual presentation of information

Theme: EYI NI OJO TO OLUWA DA

This is the day which LORD Hath Made

This LL item shows the use of more than one language where the Yoruba version is presented as the major language in font size, colour and prominence, while the English version is presented as a translation of the major information. The other use of Yoruba is to present the particular name of the programme being advertised, and this is not translated: ERI AMONA 2015. This reflects a power tussle between the two languages. On the one hand, the Yoruba language is presented to attract the audience's attention to the originality of the programme while the English language is used to announce the sophistication of the sign producer.

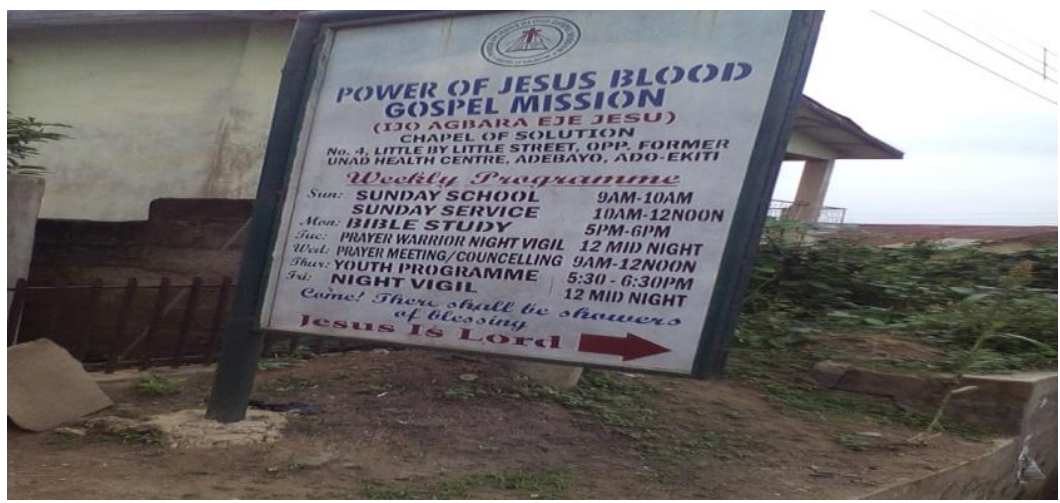

Pic 4.4.4 A bilingual church signboard with translation of brand name

Picture 4.4.4 is a bilingual sign, with English as the prominence language. The text on the signboard has the following features:

i. The first text the reader/audience encounters is written in English,

ii. The text is written in bigger font size while the Yoruba version is written in smaller font and only made noticeable by the colour.

The presence of Yoruba language, which is a translation of the preceding English text, is made prominent with the colour red. The text in Yoruba language is also presented as an appendage to the previous text. Therefore, though Yoruba language is a dominant indigenous language in Ekiti State, English language is more prominent on the LL items examined in this paper.

In bottom-up church signboards, the only instance of multilingualism shows the English language with the larger font size and as the major name of the church, while the Yoruba version has a smaller font size and is highlighted by the use of colour. This reveals the sign producer's awareness of the multilingual environment and the need to communicate to more than one set of people in the society. The LL items also depict the generic pattern of writing the name of the church or programme, in bigger fonts; alias and slogans in English; and the arrangement of the languages on the LL items to reflect the dominance of English in situations where more than one language is used. Instances where Yoruba language is used reveal, on the one hand, the indigeneity of the church, and appeal to the cultural identity and loyalty of the intended audience, and on the other hand, highlight, emphasise and make salient the information on the item.

\section{E. Islamic-related Public Signs}


TABLE 2.0

STATISTICAL ANALYSIS OF ISLAMIC-RELATED PUBLIC SignS

\begin{tabular}{|c|c|c|c|c|c|c|c|c|c|c|c|c|}
\hline \multirow[t]{3}{*}{$\mathrm{N}$} & \multirow[t]{3}{*}{ Category } & \multirow{3}{*}{\multicolumn{2}{|c|}{ Type of sign }} & \multirow[t]{3}{*}{ No of signs } & \multicolumn{2}{|c|}{ MnL. no \&\% } & \multirow{3}{*}{$\begin{array}{l}\mathrm{B} / \mathrm{ML} \\
\text { no } \\
\& \%\end{array}$} & \multicolumn{2}{|c|}{ Signal } & \multicolumn{3}{|c|}{ Brand name/title } \\
\hline & & & & & \multirow{2}{*}{$\begin{array}{l}\text { Eng } \\
\%\end{array}$} & \multirow{2}{*}{$\begin{array}{l}\mathrm{Ar} \\
\%\end{array}$} & & \multicolumn{2}{|c|}{$\mathrm{MnL}$} & \multicolumn{2}{|c|}{$\mathrm{MnL}$} & \multirow[t]{2}{*}{$\mathrm{B} / \mathrm{ML}$} \\
\hline & & & & & & & & Eng & $\operatorname{Ar} \%$ & Eng & $\mathrm{Ar}$ & \\
\hline \multirow[t]{4}{*}{1} & \multirow[t]{4}{*}{ Top-down } & \multicolumn{2}{|c|}{ Signboards } & 1 & 0 & 0 & $1=25$ & - & 1 & - & - & $1=25$ \\
\hline & & \multirow[t]{2}{*}{ Banner } & Mosque & 0 & 0 & 0 & - & - & - & - & - & - \\
\hline & & & programme & 0 & 0 & 0 & - & - & - & - & - & - \\
\hline & & \multicolumn{2}{|c|}{ Posters/others } & 0 & 0 & 0 & - & - & - & - & - & - \\
\hline \multirow[t]{5}{*}{2} & \multirow[t]{4}{*}{ Bottom-up } & \multicolumn{2}{|c|}{ Signboard } & 3 & 0 & 0 & $3=75$ & - & 1 & 0 & 0 & $3=75$ \\
\hline & & \multirow[t]{2}{*}{ Banner } & Mosque & - & - & 0 & - & - & - & - & - & - \\
\hline & & & programme & - & - & 0 & - & - & - & - & - & - \\
\hline & & \multicolumn{2}{|c|}{ Poster/others } & - & - & 0 & - & - & - & - & - & - \\
\hline & & \multicolumn{2}{|c|}{ TOTAL } & 4 & 0 & 0 & $4=100$ & 0 & $2=50 \%$ & 0 & 0 & $4=100 \%$ \\
\hline
\end{tabular}

English $=$ Eng, Arabic $=\mathrm{Ar}$

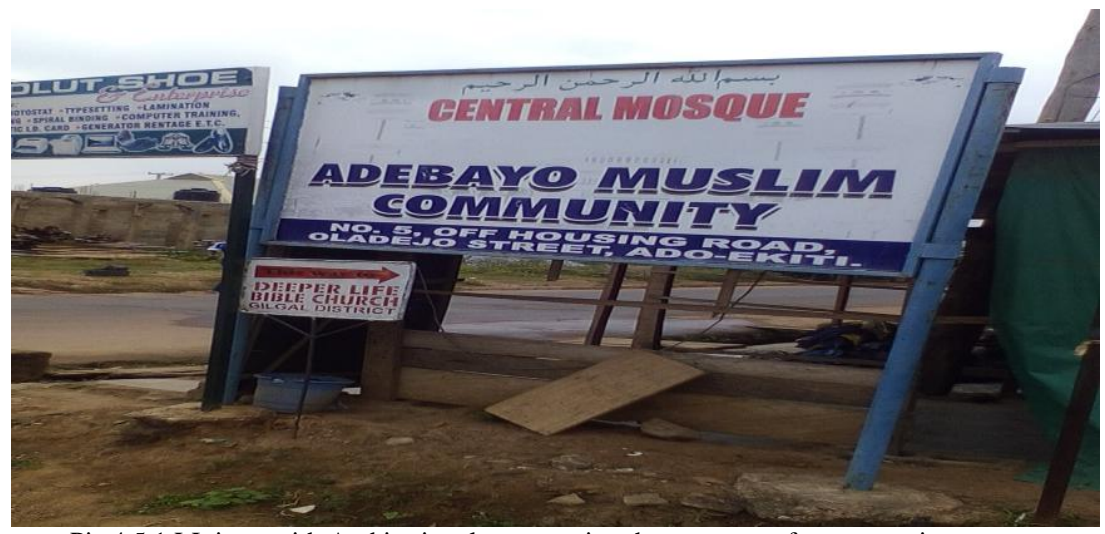

Pic 4.5.1 LL item with Arabic signal, announcing the presence of a community mosque

There are 4 Islamic related signs for this study. All the signs used in this study are signboards. One (25\%) of them is used to announce the presence of a mosque while three (75\%) are advertising the business of Arabic/Islamic doctors. The LL item announcing a mosque is a top-down sign in that it is produced by a constituted authority, while the others are bottom-up signs. In Table 2.0, all the signboards have bilingual information. Two of the signs have texts in Arabic and English (see Pic 4.5.1, Pic 4.5.4), one is produced with Arabic and Yoruba texts (see Pic 4.5.3), while the other has the combination of the three languages (see Pic 4.5.2). Two signboards (50\%) have their introductory information (signal) in Arabic but none in English (see Pics 4.5.1 and 4.5.2). The consistency of Arabic on all the Islamic-related signboards as signal, name and alias show the inherent connection of the language to the religion.

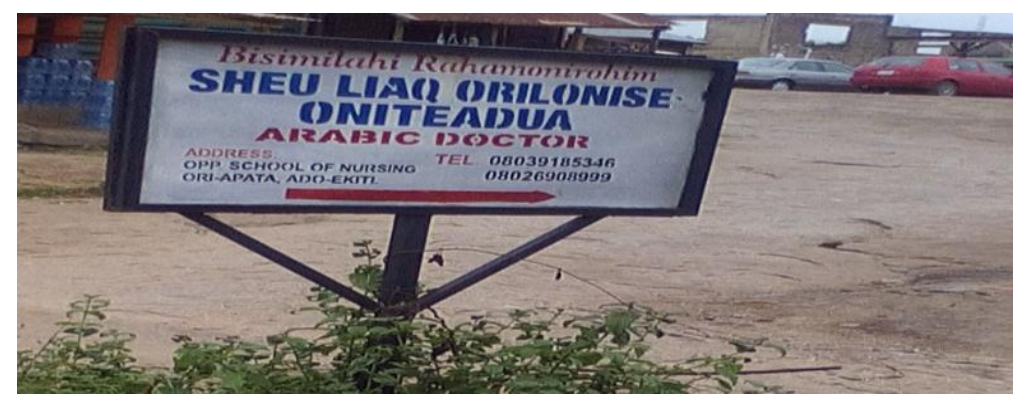

Pic 4.5.2 Item with re-orthograped Arabic signal, advertising the private practice of an Islamic cleric

The use of Arabic on Picture 4.5.1 is imperative, as it has been claimed that the language is inseparably tied to the religion (Ayuba, 2012). This same feature on Picture 4.5.2 has dual functions, as an advertisement for the business of the Arabic doctor and as a generic feature of the religion. It therefore, shows the level of knowledge the Arabic doctor has of the religion. Thus, the first texts on these signboards are written in Arabic language. The sign producer then identifies with, persuades and encourages the intended audience that the Arabic doctor is qualified and therefore worthy of their trust.

The other items, Picture 4.5.3 and Picture 4.5.4 do not have Arabic signals, but they have other features that mark them as Islamic-related signs. 


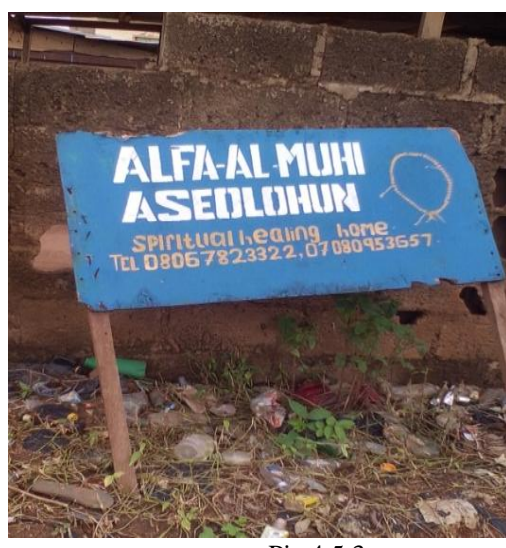

Pic 4.5.3

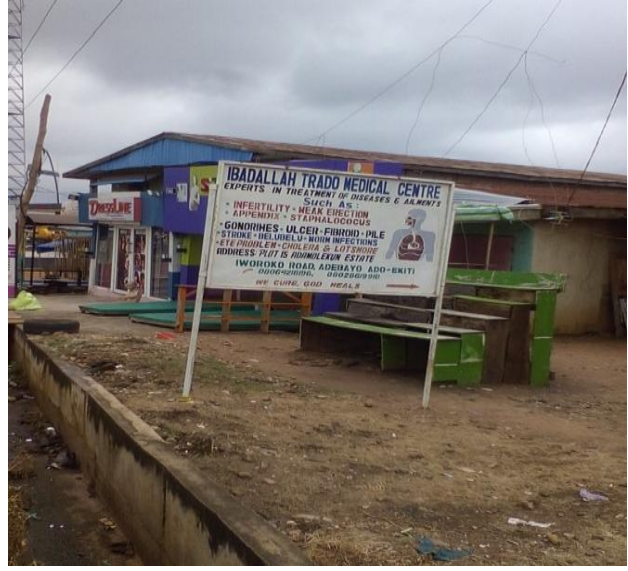

Pic 4.5.4

Also, all the bottom-up signs have bilingual names in Arabic and Yoruba. The Arabic names are Alfa-Al Muhi, Sheu Liaq and Ibadallah, while the Yoruba names are Orilonise (destiny determines ones path), Oniteadura (one who owns praying ground), Aseolorun (God's sanction). Thus, with the Arabic language, the intended audience cannot miss their connection to Islam. The type of services rendered by these Islamic clerics also reveals an appeal to religion and culture. For instance, one of these signboards has 'spiritual healing home' while the other one has 'trado-medical centre'. While spiritual healing homes are more religion-based, 'Trado-medical' is the Nigerian term for the combination of traditional and orthodox medical practices. Usually, traditional medicine combines both religious and cultural practices, and the sign producer, therefore, has appealed to both the religious and cultural consciousness of the audience.

\section{F. ATR-related Public Signs}

There is only one instance of African Traditional Religion (ATR) sign in this study. The dearth of ATR signs in Ekiti State can be attributed to the effect of globalisation by causing a massive migration from traditional values, practices and religion to what has been perceived as a more sophisticated religion, Christianity. This also accounts for people's seeming public detachment from ATR as it is more fashionable and sophisticated to not be an ATR faithful.

TABLE 3.0

SHOWING STATISTICS FOR ATR-RELATED PUBLIC SignS

\begin{tabular}{|c|c|c|c|c|c|c|c|c|c|}
\hline \multirow[t]{3}{*}{$\mathrm{S} / \mathrm{N}$} & \multirow[t]{3}{*}{ Category } & \multirow{3}{*}{\multicolumn{2}{|c|}{ Type of sign }} & \multirow[t]{3}{*}{ No of signs } & \multirow[t]{3}{*}{$\begin{array}{ll}\mathrm{B} / \mathrm{ML} & \text { no } \\
\& \% & \\
\end{array}$} & \multicolumn{2}{|c|}{ signal } & \multicolumn{2}{|c|}{ Motto } \\
\hline & & & & & & \multicolumn{2}{|l|}{$\mathrm{MnL}$} & \multirow{2}{*}{$\begin{array}{l}\text { MnL } \\
\text { (Yor) }\end{array}$} & \multirow{2}{*}{$\begin{array}{l}\mathrm{B} / \mathrm{M} \\
\mathrm{L}\end{array}$} \\
\hline & & & & & & Eng & Yor & & \\
\hline \multirow[t]{6}{*}{1} & \multirow[t]{5}{*}{ Bottom-up } & \multicolumn{2}{|c|}{ Signboard } & 1 & & 0 & - & 1 & 0 \\
\hline & & \multirow{3}{*}{ Banner } & \multirow{3}{*}{ programme } & - & 0 & 0 & - & 0 & 0 \\
\hline & & & & - & & 0 & - & 0 & 0 \\
\hline & & & & & 0 & & & & \\
\hline & & \multicolumn{2}{|c|}{ Poster/others } & & $\begin{array}{l}0 \\
0\end{array}$ & 0 & & 0 & 0 \\
\hline & & \multicolumn{2}{|c|}{ TOTAL } & 1 & $1=100$ & 0 & 0 & 1 & 0 \\
\hline
\end{tabular}

English= Eng; Yoruba $=$ Yor

This sign features an almost exclusive use of the Yoruba language (except for contact information), which evinces loyalty to the indigenous language as the language strictly to be used in carrying out ATR-related activities.

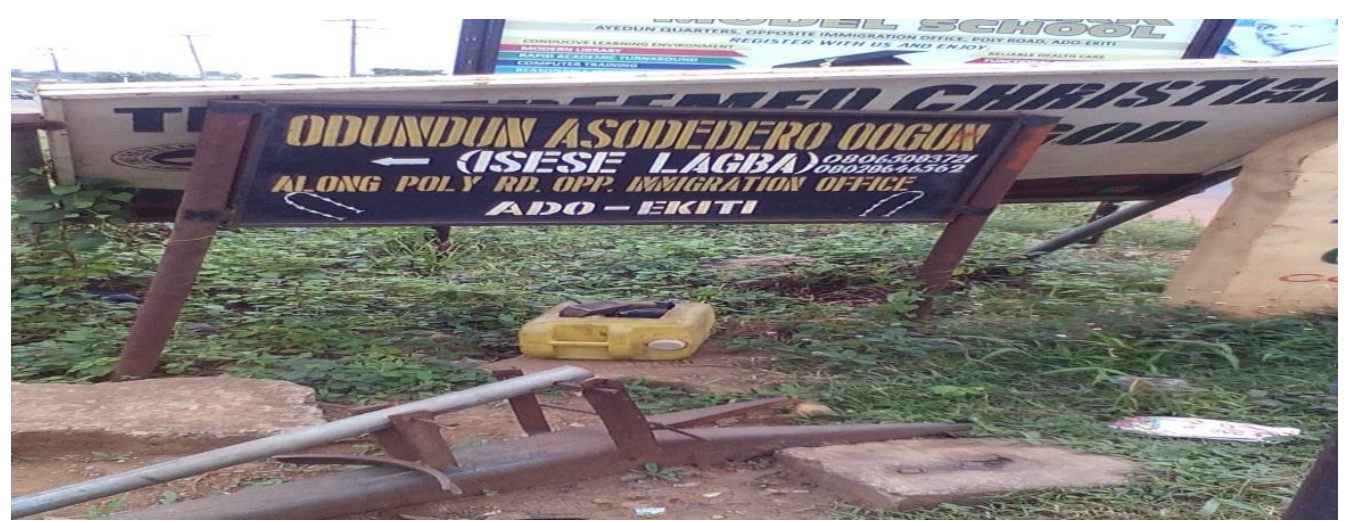

Pic 4.6.1 A monolingual ATR sign written in Yoruba 
The sign features the name of the practitioner, the slogan and the address of the practitioner. The name and the slogan of the sign producer are in Yoruba language while other information such as mobile phone number and address are in English language. This shows that mobile phones and addresses are not features of indigenous practices. Mobile phone is a product of technological development and an important aspect of globalisation. It is also an expression of sophistication. Thus, while the major information of the ATR sign is written in Yoruba language to preserve the practice and culture of the religion, the contact information is rendered in English language and this reflects, as was just mentioned, sophistication and the effect of globalisation.

\section{G. Implication for Social and Global Identity}

The analyses above reflect that the English language as a global language is given prominence over indigenous languages in LL in Nigeria. This is because the English language has an enviable social and educational status it accords its users. Thus, the dominant use of English in producing LL items demystifies the social class of the sign producer and that of the intended audience. Furthermore, it evinces the strong connection between the LL item, the producers and the audience to the English language. Therefore, the dominant use of English reveals the social status of education, sophistication and global connection.

On the other hand, the realisations of few instances of the use of the Yoruba language do not suggest lack of education or refinement, but are indicative of linguistic loyalty, as well as language ideology, particularly in the belief that the indigenous languages communicate ideas and meanings better than the 'foreign' English language. Therefore, while the large number of LL items in English point to the level of globalisation and the eagerness to identify with it, the minimal use of Yoruba points to the few conservatives and loyalists of the indigenous language, and in this case, Yoruba language. An instance of the use of the English language as an emblem of the global world and enlightenment is Picture 4.6.1 where all the information about the ATR practice is in Yoruba but the contact information is in English. The English language is also utilised to reach larger audience since not everyone in the community is versed in the indigenous language. For Christian-related signs, the English language is used for proselytism and sustaining new members. It also presents these worship centres as sophisticated, civilised and socialising where the mode of worship encourages and suits the parishioners 'wanna-be' ideology.

\section{H. Implication for Cultural and Linguistic Identity}

Languages are rooted in cultures, and humans as representatives of their culture appropriate their language for social identity. It is however, observed that the LL items are not reflexive of the actual linguistic situation in Ekiti State, a deeply linguistically indigenous state. This, therefore, shows a gap in the cultural projection of the Ado Ekiti social actors. The LL producers, as a result, identify with the foreign language as a sign of advancement and education, a characteristic of urban life, as the use of indigenous language would be tantamount to traditionalism. This is particularly the case with the Christian-related LL items.

The Islamic-related LL items are produced such that the English language projects the level of education of the social actor/sign producer. Also, Nigeria is not an Arabic speaking country and Arabic is mostly attached to the Islamic religion. Therefore, the English language used on these signs is for communicative purpose: to reach a wider audience who might otherwise not understand Arabic if it were exclusively used in producing the signs. On the other hand, Arabic is used to show both the inherent attachment of the language to the religion and to win the confidence of the audience/readers that the sign producer is knowledgeable in the ways of Islam and is therefore worthy of their trust and confidence.

\section{CONCLUSION}

Religious signage in Ado Ekiti has reflected the prominent use of English in the Christian-related signage more because Christianity is both a modern and foreign religion, which makes the use of the English language on the signs a reflection of sophistication and globalisation. This is also true about the other religions considered in this study, though as a projection rather than reflection of sophistication and globalisation. Islamic related signage use more of Arabic than English and this has two implications: one, to show the inherent attachment of the language to Islam, and two, a display of Arabic knowledge and achievement by the sign actors and producers. This is meant to gain the confidence and trust of the reader. One thing stands out in all of these; the fact that there is a dearth of the indigenous language in the linguistic landscape of this city. First, there is only one ATR sign in the public scenery. This ATR LL item used in the study has Yoruba language as the major language of communication while the English language only plays a supportive role. The Yoruba language, despite the minimal use, would assist in the documentation and survival of the indigenous language, especially in the face of the domineering and encroaching English language.

Thus, the LL shows a preference for the English language as a movement towards globalisation and sophistication. It can then be concluded that the linguistic landscape of a people may not always reflect their actual linguistic attitude, contrary to the findings in some other studies (Pavlenko, 2010; Cenoz and Gorter, 2009). This means that the ability of the linguistic landscape of a place to reveal its linguistic attitude depends on the language practices of that place: what is presented for the public to see as against what is the actual day-to-day linguistic situation. This represents the symbolic rather than emblematic use of language found in the linguistic landscape of Ado Ekiti, which is a contrast to Ben-Rafael 
et al (2006) where the LL items are emblematic of the society that produces them; an acutely multilingual society. The use of English language is a symbol of civilisation, sophistication and gravitation towards the global world rather than an emblem of the linguistic identity and language ideology of the people.

\section{REFERENCES}

[1] Aito, E. (2005). National and official languages in Nigeria: reflections on linguistic interference and the impact of language policy and politics on minority languages. In J. Cohen, K. T. McAlister, K. Rolstand, \& J.MacSwan (Eds.), Proceedings of the $4^{\text {th }}$ international symposium on bilingualism. (pp. 18-38). Sommerville, MA: Cascadilla Press

[2] Adetunji, A. (2013). A sociolinguistic study of meaning making in a Nigerian linguistic landscape: The example of Ibadan. Unpublished doctoral dissertation, Texas A\&M University-Commerce.

[3] Adogame, A. (1998). Building bridges and barricades. Marburg journal of religion. 3(1). Retrieved 16/05/2016. http://www.rchive.ub.uni-marburg.de/ep/0004.

[4] Akindele, F., \& Adegbite, W. (1999). The sociology and politics of English in Nigeria. Ile Ife: Obafemi Awolowo University Press.

[5] Ayeomoni, M. O. (2011). Migration and culture: implications on Nigerian languages. International journal of English and literature. 12(9), 155-199.

[6] Ayuba, M. A. (2012). The Arabic language: its relevance to Nigerian development. European Scientific Journal. November edition. 8(26), 192-202

[7] Backhaus, P. (2006). Multilingualism in Tokyo: a look into the linguistic landscape. In D. Gorter (Ed.), Linguistic landscape: a new approach to multilingualism. International Journal of Multilingualism. 3(1), 52-66. UK: Multilingual Matters Ltd

[8] Backhaus, P. (2007). Linguistic landscape: a comparative study of urban multilingualism in Tokyo. Multilingual matters 136. John Edwards (ed.). England: Multilingual Matters Ltd

[9] Ben Rafael, E., Shohamy, E., Muhammad H. A., \& Trumper-Hecht, N. (2006). Linguistic landscape as a symbolic construction of the public space: the case of Israel. In D. Gorter (Ed.), Linguistic landscape: a new approach to multilingualism. International journal of multilingualism. 3(1), 7-30. UK: Multilingual Matters Ltd

[10] Ben-Rafael, E. (2009). A sociological approach to the study of linguistic landscape. In E. Shohamy\& D. Gorter (Eds.), Linguistic landscape: expanding the scenery. New York: Routledge. (pp. 40-54).

[11] Cenoz, J. \& Gorter, D. (2006). Linguistic landscape and minority languages. In D. Gorter (Ed.), Linguistic landscape: a new approach to multilingualism. International Journal of Multilingualism. 3(1), 67-80. UK: Multilingual Matters Ltd.

[12] Cenoz, J. \& Gorter, D. (2009). Language economy and linguistic landscape. In E. Shohamy\& D. Gorter (Eds.), Linguistic landscape: expanding the scenery. New York: Routledge. (pp. 55-69)

[13] Gorter, Durk (2006). Introduction: the study of the linguistic landscape as a new approach to multilingualism. In D. Gorter (Ed.), Linguistic landscape: a new approach to multilingualism. International Journal of Multilingualism. 3(1), 1-6. UK: Multilingual Matters Ltd.

[14] Holt, R. (2006). A socio-linguistic approach to religious language. Australian eJournal of Theology. 6 (February 2006). Retrieved 20/06/2016. www.aejt.com/au.

[15] Huebner, T. (2006). Bangkok's linguistic landscapes: environmental print, code-mixing and language change. In D. Gorter (Ed.), Linguistic landscape: a new approach to multilingualism. International journal of multilingualism. 3(1), 67-80. UK: Multilingual Matters Ltd.

[16] Huebner, T. (2009). A framework for the linguistic analysis of LL. In E. Shohamy \& D. Gorter (Eds.), Linguistic landscape: expanding the scenery. New York: Routledge. (pp. 70-87)

[17] Inya, O. (2012a). Generic Structure Potential of Christian apologetics. Linguistik Online 55(5), 75-87.

[18] Inya, O. (2012b). 'Defending a thesis': pragmatic acts in contemporary Christian apologetics. Theory and practice in language 2(10), 2016-2023.

[19] Kamalu, I. \& Tamunobelema, I. (2013).Linguistic Expression of Religious Identity and Ideology in Selected Postcolonial Nigerian Literature. Canadian Social Science 9(4), 78-84.

[20] Kitause, R. H. \& Achunike, H. C. (2013). Religion in Nigeria from 1900-2013. Research on humanities and social sciences. 3(18). Retrieved 06/06/2016. www.iiste.org.

[21] Landry, R., \& Bourhis, R. Y. (1997). Linguistic landscape and ethnolinguistic vitality: an empirical study. Journal of language and social psychology. 16(1), 23-49

[22] Olofin A. O. (2012). Effects of English language on national development. Greener journal of social sciences. 2(4), $134-139$.

[23] Pavlenko, A. (2010). Linguistic landscape of Kyiv, Ukraine: a diachronic study. In E. Shohamy, E. Ben-Rafael \& M. Barni (Eds.), Linguistic landscape in the city. UK: Multilingual Matters. (pp. 133-152).

[24] Robert, E. and Ukpongetuk, N. (2014). Lexico-semantic features in the language of religion and advertising. Research on humanities and social sciences. 4(9), 60-72. Retrieved 06/06/2016. www.iiste.org.

[25] Robertson, R. (1995). Glocalisation: time-space and homogeneity-heterogeneity. In M Featherstone, S. Lash, and R, Robertson (Eds.), Globalmodernities. London: Sage

[26] Shohamy, E. and Gorter, D. (Eds.), (2009). Introduction. Linguistic landscape: expanding the scenery. New York: Routledge. (pp. 1-10)

[27] Shohamy, E., Ben-Rafael, E., \& Barni, M. (Eds.), (2010). Introduction. Linguistic landscape in the city. UK: Multilingual matters. (pp. 1-2)

[28] Suleiman, A. S. (2014). Religious issues and foreign language learning in Nigeria: the case of Arabic and French in Ilorin metropolis. Centrepoint journal (humanities). 17(1). Retrieved 07/02/2017. www.unilorin.edu.ng.

[29] Tamunobelema, I. (2015). Language varieties. In I. Kamalu\& I. Tamunobelema,(Eds.), Issues in the study of language and literature: theory and practice. Ibadan: Kraftbooks Ltd. (pp. 415-427) 


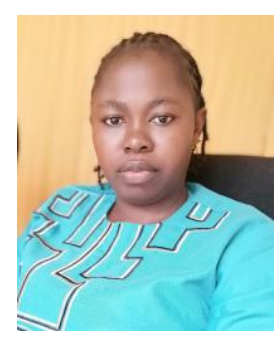

Blessing T. Inya was born in Ondo State, south-west Nigeria on $12^{\text {th }}$ of November. She got her B.A and M.A in English (language option) from the University of Ibadan, Ibadan, Oyo State, Nigeria in 2008 and 2012 respectively. She is also a prospective doctoral student at the same university.

She is currently lecturing in the Department of English and Literary studies, Federal University Oye Ekiti. She has published book chapters and journal articles on lexico-semantics, gender discourse, and humour. She is interested in discourse and gender studies. 